\title{
Acanthocephalan Worms Mitigate the Harmful Impacts of Heavy Metal Pollution on Their Fish Hosts
}

\author{
Reda Hassanine ${ }^{1, *}$ and Zaki Al-Hasawi ${ }^{2}$ D \\ 1 Biological Sciences Department, Rabigh-Faculty of Science and Arts, King Abdulaziz University, P.O. Box 344, \\ Rabigh 21911, Saudi Arabia \\ 2 Biological Sciences Department, Faculty of Science, King Abdulaziz University, P.O. Box 80203, \\ Jeddah 21589, Saudi Arabia; zalhasawy@kau.edu.sa \\ * Correspondence: rhassanine@kau.edu.sa
}

Citation: Hassanine, R.; Al-Hasawi, Z. Acanthocephalan Worms Mitigate the Harmful Impacts of Heavy Metal Pollution on Their Fish Hosts. Fishes 2021, 6, 49. https://doi.org/10.3390/ fishes 6040049

Academic Editor: Kenji Saitoh

Received: 17 September 2021

Accepted: 13 October 2021

Published: 14 October 2021

Publisher's Note: MDPI stays neutral with regard to jurisdictional claims in published maps and institutional affiliations.

Copyright: (c) 2021 by the authors. Licensee MDPI, Basel, Switzerland. This article is an open access article distributed under the terms and conditions of the Creative Commons Attribution (CC BY) license (https:// creativecommons.org/licenses/by/ $4.0 /)$.

\begin{abstract}
Toxic metal pollutants in aquatic environments and infestationwith intestinal helminths adversely affect the fish health, as well as fish consumers. Acanthocephalan worms in fish intestine have a high potential to absorb and bioaccumulate different heavy metals, especially toxic ones, from the intestine via their tegument with greater efficiency than the fish intestinal wall. Herein, 47 specimens of the fish Siganusrivulatus were trapped in the Red Sea, Egypt, from a chronically polluted bay. All were intoxicatedwith $\mathrm{Cd}$ and $\mathrm{Pb} ; 20$ (42.5\%) were uninfected with any intestinal worm, but the other 27 (57.5\%) were infected only by the intestinal acanthocephalan Sclerocollum rubrimaris. The number of individual worms in a fish host (infrapopulation size) ranged from 32 to 236. As a reference group, 22 uncontaminated-uninfected specimens of $S$. rivulatus were trapped from a small unpolluted bay. Our results revealed that infection with acanthocephalans alleviatesthe harmful effectsof toxic metalson their fish hosts by: (1) lowering the elevated concentrations of both $\mathrm{Cd}$ and $\mathrm{Pb}$ in fish liver; (2) lowering the elevated levels of liver enzymes (ALT, AST, ALP, and GGT), glucose, triglycerides, and urea in fish blood serum; and (3) raising the declined levels of total protein and albumin in fish blood serum. All of these were dependent on S. rubrimaris infrapopulation size in fish intestine.
\end{abstract}

Keywords: Sclerocollum rubrimaris; Siganus rivulatus; cadmium; lead; bioaccumulation; biochemical parameters

\section{Introduction}

Undoubtedly, fish health is adversely affected by pollution and helminth parasites. Contamination of aquatic environments with toxic heavy metals such as cadmium $(\mathrm{Cd})$, lead $(\mathrm{Pb})$, mercury $(\mathrm{Hg})$, and arsenic (As) leads to their accumulation in the different organs of fish, such as gills, intestine, liver, kidneys, and muscle [1,2]. This accumulation can cause severe tissue damage, various biochemical and functional disorders, and serious chronic diseases in these organs [3-6]. Liver is one of the major metabolically active organs in the body and is the main detoxification site, and its tissue tends to accumulate higher levels of heavy metals than any other tissues in the body [7-13]. Acanthocephala is a small phylum of mesoparasitic and gonochoristic worms. The adults are extremely specialized to live in the digestive tract of vertebrates, especially fish, where they use their armed proboscis to attach to the intestinal mucosa or to the intestinal wall. However, these worms have no digestive tract and absorb their nutrients through their tegument [14]. Generally, acanthocephalans adversely affect and damage the nature of intestinal tissue at the attachment sites, causing severe histopathological changes [15-22].

Over the years 1995-2020, a large number of valuable studies have demonstrated that fish helminth parasites, especially those that do not have a digestive tract (i.e., acanthocephalans and cestodes), actively use their tegument to absorb nutrients from the fish'sintestine. Thus, these helminthsare good sentinels for trace metal pollution in aquatic environments 
since they have much higher potential and capacity than their fish hosts to bioaccumulate different metals, especially toxic ones, from the fish's intestine [13,23-29]. This process may affect the physiology of the fish hosts by lowering the amount of metals available in their intestine before absorption through the intestinal wall to other organs. If these metals are toxic, then the parasites have a beneficial impact on their fish hosts, by minimizing the amounts of these metals in their tissues [13,23,30,31]. Confirming this, several studies have shown that metal concentrations in the tissues of acanthocephalan-infected fish were significantly less than those of uninfected conspecifics [13,28,32-35].

In fishes, the levels of blood biochemical parameters are commonly used to assess their health status. For example, the levels of serum liver enzymes (alanine amino transferase ALT, aspartate amino transferase AST, alkaline phosphatase ALP, and gamma-glutamyl transferase GGT) are used to assess the liver functions and hepatocyte integrity [36,37]. Thelevels of serum glucose and triglycerides are used to assess the processes of energy metabolism [38,39], and the levels of serum total protein STP, albumin, and urea are used to assess the processes of protein metabolism and growth $[40,41]$. These parameters are sensitive, and their levels significantly altered in fishes living in metal-polluted environments, leading to serious health problems and diseases [42-45]. Additionally, several studies [46-51] have demonstrated that fish infection with helminth parasites significantly increases the levels of blood biochemical parameters.

The siganid fish Siganus rivulatus is common and an important fishery target in the Red Sea and is specifically parasitized by the acanthocephalan Sclerocollum rubrimaris Schmidt and Paperna, 1978 [28,52-54]. It is economically important, easy to obtain, and the only fish parasitized with acanthocephalans. In the present study, this host-parasite system was found resident in a chronically polluted small bay named "Boat Harbour", at Sharm El-Sheikh, South Sinai, Egypt, and was used to estimate the acanthocephalans' uptake of toxic metals from the intestine of their fish hosts and to assess for the first time the corresponding impacts of this uptake on some biochemical parameters in these hosts (liver function parameters, energy metabolism parameters, and protein metabolism parameters), and whether these impacts were harmful or beneficial to these hosts.

\section{Materials and Methods}

\subsection{Ethics}

This work complied with the current Egyptian regulations of Institutional Animal Care and Use Committee (local IACUC-Cairo University, Cairo, Egypt: approval code, $\mathrm{CU} / \mathrm{F} / 8365$ : 7/1/2020), the Egyptian universities guidelines for the care of experimental animals, and with the Egyptian Environmental Affairs Agency (EEAA).

\subsection{Samples Collection and Preparation}

During February of 2020, a sample of 47 specimens of the teleost fish Siganus rivulatus (Siganidae), approximately with equal sizes (20.87 $\pm 1.83 \mathrm{~cm}$ in total length), were trapped alive by a small conical fishing hand net (during scuba diving) in the Red Sea, from

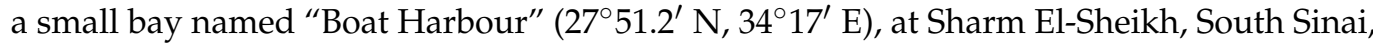
Egypt (Figure 1). This bay is chronically or severely polluted due to the huge discharge of untreated sewage and other wastes from a large number of motorboats directly into this bay. However, and during the same month, 22 specimens of this fish, also with nearly equal sizes $(20.14 \pm 2.10 \mathrm{~cm}$ in total length), were taken alive from a small uninhabited and clear bay near Safaga (133 km south of Sharm El-Sheikh) (Figure 1), far away from anthropogenic pollution sources.

To detect the metal pollution in the two bays, 5 sets of water samples, each composed of 3 replicates $(100 \mathrm{~mL})$, were taken from different sites in each bay. Each replicate was filtered and preserved with $2 \mathrm{~mL}$ of $\mathrm{HNO}_{3}$. Within 40 min after trapping, fishes were anesthetized with benzocaine, and a blood sample of $10 \mathrm{~mL}$ was taken aseptically from the caudal vein of each fish via a $10 \mathrm{~mL}$ disposable syringe; this step was carried out quickly to reduce fish stress. Then, the blood sample was transferred into a blood collection tube (Becton 
Dickinson, Vacutainer Plus Serum Blood Collection Tube, $6 \mathrm{~mL}$ ), left undisturbed and allowed to clot for $30 \mathrm{~min}$ at room temperature $\left(25^{\circ} \mathrm{C}\right)$. Finally, the sample was centrifuged (Eppendorf $5810 \mathrm{R}$, Hamburg, Germany) at $2000 \mathrm{rpm}$ for $10 \mathrm{~min}$, and the formed serum was immediately transferred into a clean polypropylene tube. The collected blood sera were stored frozen at $-25{ }^{\circ} \mathrm{C}$ until being processed for various biochemical analyses.

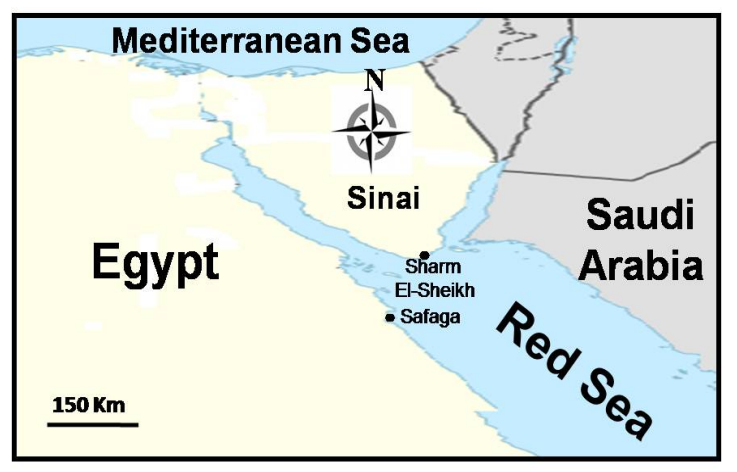

Figure 1. A map showing the location of Sharm El-Sheikh, South Sinai, Egypt, and Safaga (133 km south of Sharm El-Sheikh).

After dissection, a sample was taken from the liver of each fish and kept frozen at $-20{ }^{\circ} \mathrm{C}$ until being processed for metal analysis. All individuals (infrapopulation) of Sclerocollum rubrimaris Schmidt et Paperna, 1978, found in the intestine of each infected fish were carefully teased out and counted; 20 worms were haphazardly taken from each infected fish as a representative sample of this parasite, perfectly homogenized into a composite, and then kept frozen at $-20^{\circ} \mathrm{C}$ until being processed for metal analysis.

To minimize probability of sample contamination, standard precautions such as using highly sterilized stainless steel dissection instruments, highly sterilized vessels for tissues digestion, high-quality analytical reagents, and clean plastic vials with lids for preservation of tissues and samples were followed during the collection and treatment of samples.

\subsection{Samples Analyses}

Seawater samples were filtered through a $0.4 \mu \mathrm{m}$ membrane filter and acidified with nitric acid $65 \%$ Suprapur ${ }^{\circledR}$ to $\mathrm{pH}$ less than 2 , then analyzed directly for the heavy metals $(\mathrm{Cd}$ and $\mathrm{Pb})$ in Perkin Elmer Inductively Coupled Plasma-Mass Spectrometer (ICP-MS; ELAN6100, Concord, ON, Canada). Metal concentrations in water samples are expressed as $\mu \mathrm{gL}^{-1}$.

Three replicates from eachcollected blood serumwere used to estimate some liver function parameters (the enzymes alanine amino transferase ALT, aspartate amino transferase AST, alkaline phosphatase ALP, gamma-glutamyl transferase GGT), some energy metabolism parameters (glucose and triglycerides), and some protein metabolism parameters (serum total protein STP, albumin and urea) in all the examined fishes. All these parameters were measured using the AU5800 Automated Clinical Chemistry Analyzer (Beckman Coulter Inc., Brea, CA, USA); ALT, AST, ALP, GGT, glucose, triglycerides, STP, albumin and urea were measured at wavelengths of 340, 340, 450,440, 360, 680, 700, 600, and $340 \mathrm{~nm}$.

Three replicates from each fish liver sample or from each parasite composite sample were analyzed for heavy metals $(\mathrm{Cd}$ and $\mathrm{Pb})$ as recommended by Zimmermann et al. [55] and Nachev [56]. After thawing, $150 \mathrm{mg}$ (wet weight) of homogenized fish liver or $40 \mathrm{mg}$ of the parasite composite was placed in $150 \mathrm{~mL}$ perfluoralkoxy (PFA) vessel. For sample digestion, $2 \mathrm{~mL}$ of nitric acid $65 \%$ Suprapure ${ }^{\circledR}$ and $2.5 \mathrm{~mL}$ of hydrogen peroxide $30 \%$ Suprapure ${ }^{\circledR}$ were mixed and the mixture was poured into the vessel, which was heated for $90 \mathrm{~min}$. at about $170{ }^{\circ} \mathrm{C}$ in a microwave digestion system (CEM GmbH, Kamp-Lintfort, Germany; Model MDS). The obtained solution was diluted to $5 \mathrm{~mL}$ Molecular Grade Water ${ }^{\mathrm{TM}}$ in a volumetric glass flask, and then analyzed for heavy metals in the above-named instru- 
ment. Metal concentrations in the tissue samples are expressed as $\mathrm{mg} \mathrm{kg}^{-1}$ wet weight. Two standard reference materials were used to test the accuracy of ICP-MS analyses: (1) SRM-NIST 1640-Trace Elements in NaturalWater (National Institute of Standards and Technology, Gaithersburg, MD, USA), and (2) Dogfish liver-DOLT-5 (National Research Council, Ottawa, ON, Canada).

\subsection{Data Analysis}

Parasitological terms used in this study follow those of previous studies $[57,58]$. Confidence intervals (CI) were used to estimate the certainty of mean intensity of infection and mean abundance of parasite. Duncan's Multiple Range Test [59] was applied to test for differences between levels of liver enzymes, other blood parameters, and $\mathrm{Cd}$ and $\mathrm{Pb}$ concentrations in the worm and its host. Linear regression analyses were used to determine possible relationships between metal concentrations in both fish liver and worm and worm infrapopulation size in fish intestine or between levels of liver enzymes (ALT, AST, ALP and GGT), energy metabolism parameters (glucose and triglycerides), or protein metabolism parameters (total protein STP, albumin and urea) in fish blood serum and worm infrapopulation size in fish intestine. The Graph Pad PRISM 7.0 statistical package (GraphPad Software, San Diego, CA, USA) was used for data analyses.

\section{Results}

Cadmium and lead concentrations recovered from the certified reference materials, the accuracy or the quality of the analytical technique, and the detection limits of each metal are shown in Table 1.

Table 1. $\mathrm{Cd}$ and $\mathrm{Pb}$ concentrations in standard reference materials and accuracy and detection limits determined by ICP-MS analyses.

\begin{tabular}{|c|c|c|c|c|c|c|c|c|}
\hline \multirow{3}{*}{ Metal } & \multicolumn{8}{|c|}{ Standard Reference Materials } \\
\hline & \multicolumn{4}{|c|}{ SRM-NIST 1640-Trace Elements in Natural Water } & \multicolumn{4}{|c|}{ Dogfish Liver DOLT-5 } \\
\hline & $\begin{array}{l}\text { Certified Value } \\
\quad\left(\mathrm{mg} \mathrm{L}^{-1}\right)\end{array}$ & $\begin{array}{c}\text { Recovered Value } \\
\left(\mathrm{mg} \mathrm{L}^{-1}\right)\end{array}$ & $\begin{array}{c}\text { Accuracy } \\
(\%)\end{array}$ & $\begin{array}{l}\text { Detection Limit } \\
\left(\mathrm{mg} \mathrm{L}^{-1}\right)\end{array}$ & $\begin{array}{c}\text { Certified Value } \\
(\mathrm{mg} / \mathrm{km})\end{array}$ & $\begin{array}{c}\text { Recovered Value } \\
(\mathrm{mg} / \mathrm{km})\end{array}$ & $\begin{array}{c}\text { Accuracy } \\
(\%)\end{array}$ & $\begin{array}{l}\text { Detection Limit } \\
(\mathrm{mg} / \mathrm{km})\end{array}$ \\
\hline $\mathrm{Cd}$ & $3.961 \pm 0.072$ & $3.904 \pm 0.016$ & 98.56 & 0.007 & $14.5 \pm 0.400$ & $14.26 \pm 0.019$ & 98.34 & 0.004 \\
\hline $\mathrm{Pb}$ & $12.005 \pm 0.040$ & $11.550 \pm 0.014$ & 96.20 & 0.008 & $0.16 \pm 0.036$ & $0.154 \pm 0.022$ & 96.25 & 0.006 \\
\hline
\end{tabular}

\subsection{Metal Pollution and Intestinal Helminth Parasites of Fishes in the Two Bays}

Heavy metals including $\mathrm{Cd}$ and $\mathrm{Pb}$ were undetectable in all water and fish liver samples taken from the small uninhabited bay at Safaga, which appeared to have clean natural environment. However, no intestinal helminth parasites were observed in the examined fishes taken from this bay; these fishes seemed to be healthy, and were therefore considered as a "reference group", i.e., "uncontaminated-uninfected fishes". In contrast, $\mathrm{Cd}$ and $\mathrm{Pb}$ were readily detectable in all water and fish liver samples taken from the chronically polluted Boat Harbour, where mean $\mathrm{Cd}$ and $\mathrm{Pb}$ concentrations in its water were $0.138 \pm 0.006$ and $1.525 \pm 0.005$, respectively (see below). Of the 47 examined fishes from this bay, 20 (42.5\%) were uninfected with any intestinal worm, i.e., "contaminateduninfected fishes", while the other 27 (57.5\%) were slightly or intensely infected by an intestinal acanthocephalan worm named Sclerocollum rubrimaris Schmidt et Paperna, 1978, i.e., "contaminated-infected fishes"; no other intestinal worms were found in the examined fishes. The infrapopulation size of $S$. rubrimaris ranged from 32 to 236 individuals / fish host, with a mean intensity of $134.29 \pm 61.9$ worms / fish host $(95 \% \mathrm{CI}=75.80$, 198.77) and mean abundance of 77.14 worm / fish $(95 \% \mathrm{CI}=74.48,79.79)$.

\subsection{Serum Biochemical Parameters in Uncontaminated-Uninfected Fishes (Reference Group)}

In their blood sera, the mean levels of liver enzymes, ALT, AST, ALP, and GGT were $60.65 \pm 3.26,77.76 \pm 4.02,43.02 \pm 2.88$, and $8.46 \pm 1.26 \mathrm{U} / \mathrm{L}$, respectively (Table 2), and mean levels of other serum biochemical parameters, glucose, triglycerides, total protein, albumin and urea were $66.09 \pm 2.80 \mathrm{mg} / \mathrm{dL}, 114.29 \pm 3.20 \mathrm{mg} / \mathrm{dL}, 22.32 \pm 2.76 \mathrm{~g} / \mathrm{L}$, 
$10.46 \pm 01.76 \mathrm{~g} / \mathrm{L}$, and $28.45 \pm 1.66 \mathrm{mg} / \mathrm{dL}$, respectively (Table 3 ). These values were considered herein as the means of baseline levels since they were measured in uncontaminateduninfected fishes living in a natural, unpolluted environment.

Table 2. $\mathrm{Cd}$ and Pb concentrations and levels of serum liver enzymes (ALT, AST, ALP and GGT) in the reference group, and in the contaminated-uninfected and contaminated-infected individuals of the fish Siganus rivulatus.

\begin{tabular}{|c|c|c|c|c|c|c|c|c|}
\hline \multirow[t]{2}{*}{ Fish } & \multirow[t]{2}{*}{$\begin{array}{l}\text { No. Worms in Fish Intestine } \\
\text { (Infrapopulation Size) }\end{array}$} & \multicolumn{3}{|c|}{$\begin{array}{c}\text { Metal in Fish Liver } \\
\text { (mg kg }{ }^{-1} \text { Wet Weight) }\end{array}$} & \multicolumn{4}{|c|}{ Fish Serum Parameter (Enzymes) } \\
\hline & & & $\mathrm{Cd}$ & $\mathrm{Pb}$ & $\operatorname{ALT}(\mathrm{U} / \mathrm{L})$ & AST(U/L) & $\operatorname{ALP}(\mathrm{U} / \mathrm{L})$ & GGT (U/L) \\
\hline \multirow{2}{*}{$\begin{array}{l}\text { Reference } \\
\text { group } \\
(\mathrm{n}=22)\end{array}$} & \multirow[t]{2}{*}{ - } & Range & $\begin{array}{c}\text { Not } \\
\text { detectable }\end{array}$ & $\begin{array}{c}\text { Not } \\
\text { detectable }\end{array}$ & $55.28-65.64$ & $71.25-84.76$ & $38.78-46.83$ & $6.30-10.70$ \\
\hline & & Mean \pm SD & - & - & $60.65 \pm 3.26$ & $77.76 \pm 4.02$ & $43.02 \pm 2.88$ & $8.46 \pm 1.26$ \\
\hline \multirow{2}{*}{$\begin{array}{l}\text { Contaminated- } \\
\text { uninfected } \\
(\mathrm{n}=20)\end{array}$} & \multirow[t]{2}{*}{ - } & Range & $0.196-0.367$ & $1.588-3.168$ & $81.82-110.08$ & $98.45-126.45$ & $53.24-86.92$ & $10.03-16.86$ \\
\hline & & Mean \pm SD & $0.267 \pm 0.046$ & $2.278 \pm 0.46$ & $96.02 \pm 7.47$ & $115.04 \pm 7.43$ & $67.54 \pm 10.90$ & $13.64 \pm 2.17$ \\
\hline \multirow{2}{*}{$\begin{array}{l}\text { Contaminated- } \\
\text { infected } \\
(\mathrm{n}=27)\end{array}$} & \multirow{2}{*}{$32-236$} & Range & 0.088-0.197 & 0.943-1.912 & $72.01-93.28$ & 81.02-108.16 & $45.11-71.32$ & $7.15-12.93$ \\
\hline & & Mean \pm SD & $0.143 \pm 0.02$ & $1.47 \pm 0.21$ & $80.35 \pm 6.88$ & $91.31 \pm 8.46$ & $58.58 \pm 7.43$ & $10.31 \pm 1.62$ \\
\hline
\end{tabular}

Table 3. $\mathrm{Cd}$ and $\mathrm{Pb}$ concentrations and levels of serum glucose, albumin, total protein STP, and triglycerides in the reference group, in the contaminated-uninfected, and in the contaminated-infected individuals of the fish Siganus rivulatus.

\begin{tabular}{|c|c|c|c|c|c|c|c|c|c|}
\hline \multirow{2}{*}{ Fish } & \multirow{2}{*}{$\begin{array}{l}\text { No. Worms in Fish } \\
\text { Intestine } \\
\text { (Infrapopulation Size) }\end{array}$} & \multicolumn{3}{|c|}{$\begin{array}{c}\text { Metal in Fish Liver } \\
\text { (mg kg }{ }^{-1} \text { Wet Weight) }\end{array}$} & \multicolumn{5}{|c|}{ Fish Serum Parameter } \\
\hline & & & $\mathrm{Cd}$ & $\mathrm{Pb}$ & $\begin{array}{l}\text { Glucose } \\
\text { (mg/dL) }\end{array}$ & $\begin{array}{l}\text { Triglycerides } \\
\text { (mg/dL) }\end{array}$ & $\begin{array}{l}\text { Total Protein } \\
\text { (g/L) }\end{array}$ & $\underset{(g / L)}{\text { Albumin }}$ & $\begin{array}{c}\text { Urea } \\
(\mathrm{mg} / \mathrm{dL})\end{array}$ \\
\hline \multirow{2}{*}{$\begin{array}{l}\text { Reference } \\
\text { group } \\
(\mathrm{n}=22)\end{array}$} & \multirow[t]{2}{*}{-} & Range & Not detectable & Not detectable & $62.72-70.73$ & $109.23-117.83$ & $17.65-26.52$ & $7.97-13.77$ & $26.21-31.25$ \\
\hline & & Mean \pm SD & - & - & $66.09 \pm 2.80$ & $114.29 \pm 3.20$ & $22.32 \pm 2.76$ & $10.46 \pm 01.76$ & $28.45 \pm 1.66$ \\
\hline \multirow{2}{*}{$\begin{array}{l}\text { Contaminated- } \\
\text { uninfected } \\
(\mathrm{n}=20)\end{array}$} & \multirow[t]{2}{*}{-} & Range & $0.196-0.367$ & $1.588-3.168$ & $102.67-125.48$ & $148.49-172.53$ & $12.15-16.53$ & $4.08-7.20$ & $42.34-55.27$ \\
\hline & & Mean \pm SD & $0.267 \pm 0.046$ & $2.278 \pm 0.46$ & $112.15 \pm 6.87$ & $161.66 \pm 7.95$ & $14.44 \pm 1.28$ & $6.97 \pm 0.90$ & $49.31 \pm 3.70$ \\
\hline \multirow{2}{*}{$\begin{array}{l}\text { Contaminated- } \\
\text { infected } \\
(\mathrm{n}=27)\end{array}$} & \multirow{2}{*}{$32-236$} & Range & $0.088-0.197$ & $0.943-1.912$ & $79.80-100.71$ & $126.35-151.03$ & $16.57-20.53$ & $6.32-10.45$ & $33.06-45.48$ \\
\hline & & Mean \pm SD & $0.14 \pm 0.02$ & $1.47 \pm 0.21$ & $88.82 \pm 6.77$ & $136.66 \pm 6.97$ & $18.57 \pm 1.23$ & $8.56 \pm 1.20$ & $38.09 \pm 3.71$ \\
\hline
\end{tabular}

\subsection{Serum Biochemical Parameters in Contaminated-Uninfected Fishes}

Mean $\mathrm{Cd}$ and $\mathrm{Pb}$ concentrations in the livers of these fishes were high $(0.267 \pm 0.04$ and $2.278 \pm 0.46 \mathrm{mg} \mathrm{kg}^{-1}$ wet weight, respectively) (Table 2). Compared to those of the reference group, mean levels of serum liver enzymes (ALT, AST, ALP, and GGT) were significantly higher $(p<0.05)$ (Table 2$)$. Similarly, mean levels of serum glucose and triglycerides were significantly higher $(p<0.05)$, while mean levels of serum total protein and albumin were significantly lower $(p<0.05)$, but mean level of serum urea was significantly higher $(p<0.05)$ (Table 3$)$. These results point to significant changes or abnormalities in serum biochemical parameters of contaminated-uninfected fishes.

\subsection{Serum Biochemical Parameters in Contaminated-Infected Fishes}

Mean $\mathrm{Cd}$ and $\mathrm{Pb}$ concentrations in the livers of these fishes $(0.143 \pm 0.02$ and $1.47 \pm 0.21 \mathrm{mg} \mathrm{kg}^{-1}$ wet weight, respectively) were lower than those in contaminateduninfected fishes (Table 2). Contaminated-infected fishes were organized according to the total number of $S$. rubrimaris in each fish intestine (infrapopulation size) (Table 4). Mean concentrations of $\mathrm{Cd}$ and $\mathrm{Pb}$ in the worm $\left(13.147 \pm 2.51\right.$ and $20.11 \pm 3.70 \mathrm{mg} \mathrm{kg}^{-1}$ wet weight, respectively) were significantly much higher than those in the livers of their fish hosts $(p<0.05)$ (Table 4$)$, i.e., the acanthocephalan worm S. rubrimaris bioconcentrates $\mathrm{Cd}$ and $\mathrm{Pb}$ with about 91 and 13-fold higher than in fish liver. Negative relationships were found between $\mathrm{Cd}$ or $\mathrm{Pb}$ concentrations in fish liver and worm infrapopulation size $\left(R^{2}=0.8967, p<0.0001 ; R^{2}=0.7695, p<0.0001\right.$, respectively) (Figure 2a,b), i.e., as the worm infrapopulation size in fish intestine increased the concentration of both $\mathrm{Cd}$ and $\mathrm{Pb}$ in fish liver decreased. Additionally, clear negative relationships were found between $\mathrm{Cd}$ or $\mathrm{Pb}$ concentrations in the worm and its infrapopulation size $\left(R^{2}=0.7480, p<0.0001\right.$; $R^{2}=0.7812, p<0.0001$, respectively) (Figure $2 \mathrm{c}, \mathrm{d}$ ), i.e., as the worm infrapopulation size increased, both $\mathrm{Cd}$ and $\mathrm{Pb}$ concentrations in its individuals significantly decreased. Thus, 
metal concentrations in the fish liver and in the worm appear to be primarily dependent on worm infrapopulation size in fish intestine.

Table 4. Cadmium and $\mathrm{Pb}$ concentrations in 27 infrapopulations of the acanthocephalan worm S. rubrimaris and in the liver of their contaminated fish hosts (Siganus rivulatus).

\begin{tabular}{|c|c|c|c|c|c|}
\hline \multirow{2}{*}{ No. Fish } & \multirow{2}{*}{$\begin{array}{l}\text { No. Worms in Fish Intestine } \\
\text { (Infrapopulation Size) }\end{array}$} & \multicolumn{2}{|c|}{ Cd (mg kg ${ }^{-1}$ Wet Weight) } & \multicolumn{2}{|c|}{$\mathrm{Pb}$ (mg kg ${ }^{-1}$ Wet Weight) } \\
\hline & & Fish Liver & Worm & Fish Liver & Worm \\
\hline 1 & 32 & 0.189 & 14.268 & 1.834 & 21.453 \\
\hline 2 & 45 & 0.163 & 15.762 & 1.673 & 24.876 \\
\hline 3 & 56 & 0.171 & 18.193 & 1.776 & 23.172 \\
\hline 4 & 63 & 0.197 & 16.342 & 1.611 & 26.382 \\
\hline 5 & 69 & 0.165 & 17.872 & 1.912 & 25.371 \\
\hline 6 & 75 & 0.178 & 16.237 & 1.732 & 24.746 \\
\hline 7 & 81 & 0.164 & 16.214 & 1.602 & 26.136 \\
\hline 8 & 86 & 0.174 & 15.438 & 1.504 & 25.258 \\
\hline 9 & 91 & 0.158 & 14.984 & 1.588 & 22.313 \\
\hline 10 & 93 & 0.161 & 13.123 & 1.474 & 23.459 \\
\hline 11 & 105 & 0.147 & 14.872 & 1.501 & 18.402 \\
\hline 12 & 113 & 0.152 & 12.457 & 1.421 & 20.836 \\
\hline 13 & 124 & 0.142 & 13.741 & 1.534 & 21.238 \\
\hline 14 & 133 & 0.148 & 11.763 & 1.488 & 19.418 \\
\hline 15 & 139 & 0.154 & 10.571 & 1.507 & 18.472 \\
\hline 16 & 147 & 0.138 & 12.234 & 1.358 & 17.943 \\
\hline 17 & 159 & 0.132 & 11.873 & 1.523 & 16.634 \\
\hline 18 & 164 & 0.148 & 11.243 & 1.440 & 18.391 \\
\hline 19 & 172 & 0.124 & 12.384 & 1.389 & 19.146 \\
\hline 20 & 177 & 0.130 & 10.236 & 1.483 & 17.541 \\
\hline 21 & 182 & 0.119 & 11.763 & 1.301 & 15.382 \\
\hline 22 & 199 & 0.112 & 10.505 & 1.285 & 16.637 \\
\hline 23 & 218 & 0.105 & 10.652 & 1.375 & 15.812 \\
\hline 24 & 216 & 0.114 & 9.894 & 0.943 & 16.211 \\
\hline 25 & 222 & 0.088 & 11.611 & 1.189 & 15.533 \\
\hline 26 & 229 & 0.106 & 9.921 & 1.201 & 16.432 \\
\hline \multirow[t]{3}{*}{27} & 236 & 0.097 & 10.841 & 1.126 & 15.961 \\
\hline & Range & $0.088-0.197$ & 9.894-18.193 & $0.943-1.912$ & $15.382-26.382$ \\
\hline & Mean $\pm \mathrm{SD}$ & $0.143 \pm 0.02$ & $13.147 \pm 2.51$ & $1.47 \pm 0.21$ & $20.12 \pm 3.70$ \\
\hline
\end{tabular}

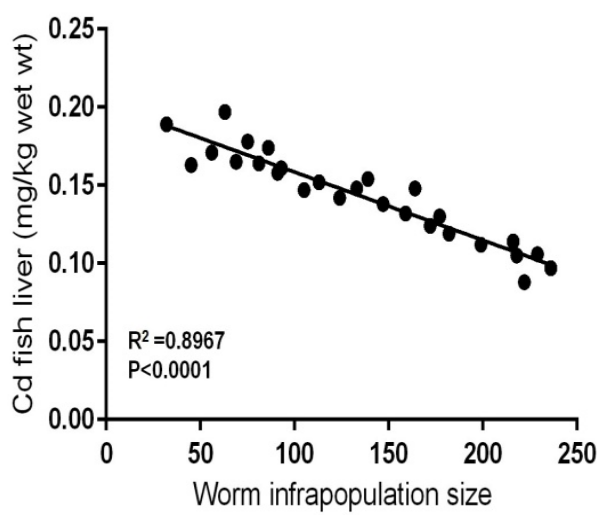

(a)

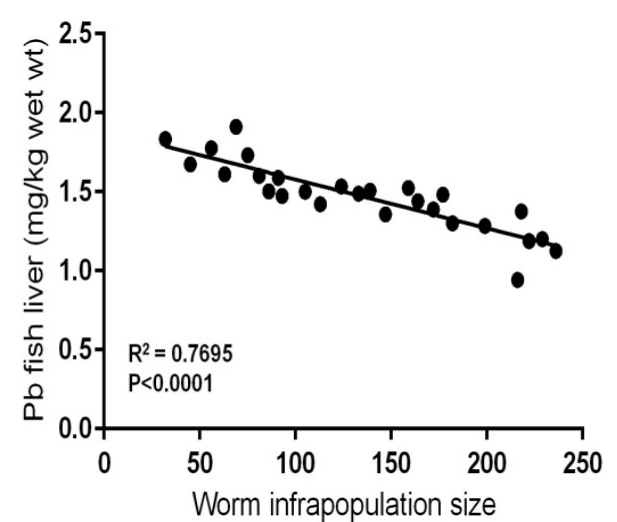

(b)

Figure 2. Cont. 


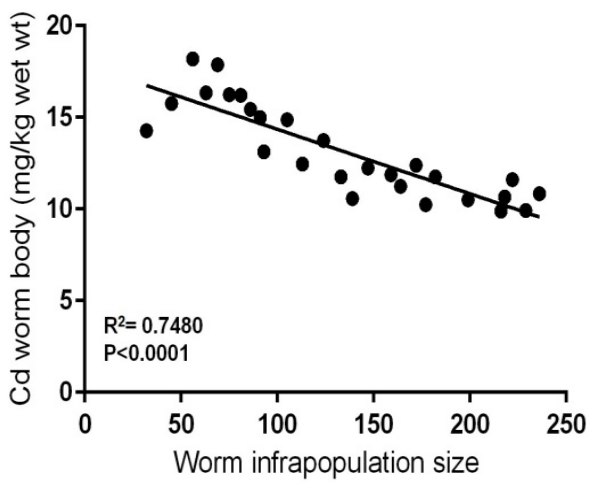

(c)

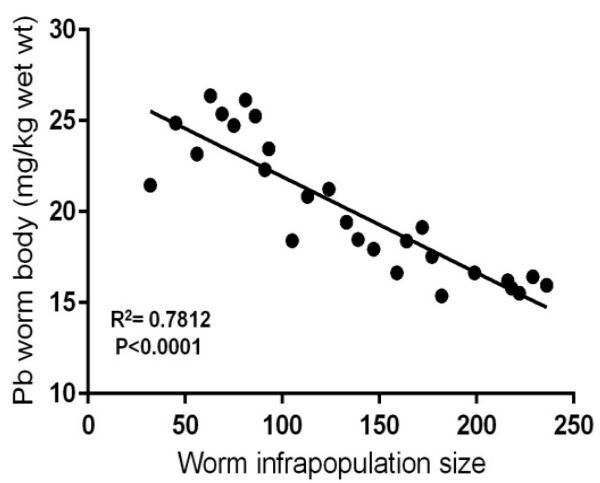

(d)

Figure 2. The relationships between metal concentrations in fish liver or in worm body and worm infrapopulation size in fish intestine: (a) Cd concentrations in fish liver vs. worm infrapopulation size, (b) Pb concentrations in fish liver vs. worm infrapopulation size, (c) Cd concentrations in worm body vs. its infrapopulation size, (d) Pb concentrations in worm body vs. infrapopulation size.

The mean levels of serum liver enzymes, ALT, AST, ALP, and GGT in contaminatedinfected fishes were significantly lower than those in contaminated-uninfected fishes $(p<0.05)$ (Table 2), and clear negative relationships were found between levels of these enzymes and worm infrapopulation size $\left(R^{2}=0.744, p<0.0001 ; R^{2}=0.8309, p<0.0001\right.$; $R^{2}=0.8834, p<0.0001 ; R^{2}=0.8675, p<0.0001$, respectively) (Figure 3a-d). Similarly, mean levels of serum glucose and triglycerides in contaminated-infected fishes (Table 3 ) were significantly lower than those in contaminated-uninfected fishes $(p<0.05)$, and clear negative relationships were found between these levels and worm infrapopulation size $\left(R^{2}=0.8618\right.$, $p<0.0001 ; R^{2}=0.8445, p<0.0001$ ) (Figure 4a,b). However, mean levels of serum total protein and albumin in contaminated-infected fishes were higher than those in contaminateduninfected fishes (Table 3), and clear positive relationships were found between these levels and worm infrapopulation size $\left(R^{2}=0.7609, p<0.0001 ; R^{2}=0.7697, p<0.0001\right)$ (Figure $4 \mathrm{c}, \mathrm{d}$ ).Moreover, mean level of serum urea in contaminated-infected fishes was significantly lower than that in contaminated-uninfected fishes $(p<0.05)$ (Table 3), and a clear negative relationship was found between this level and worm infrapopulation size $\left(R^{2}=0.8339, p<0.0001\right)$ (Figure 4e).

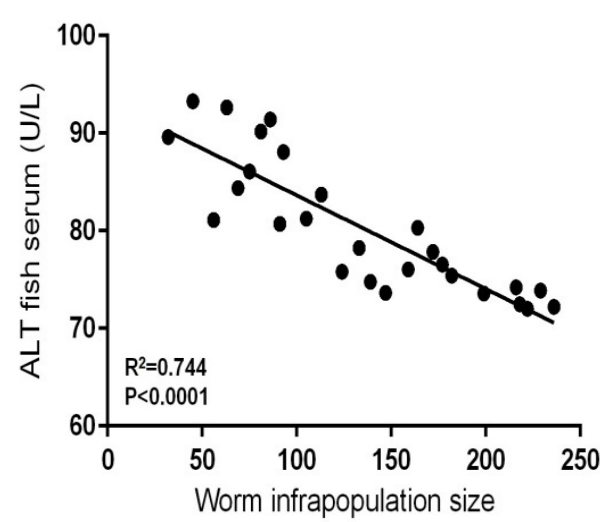

(a)

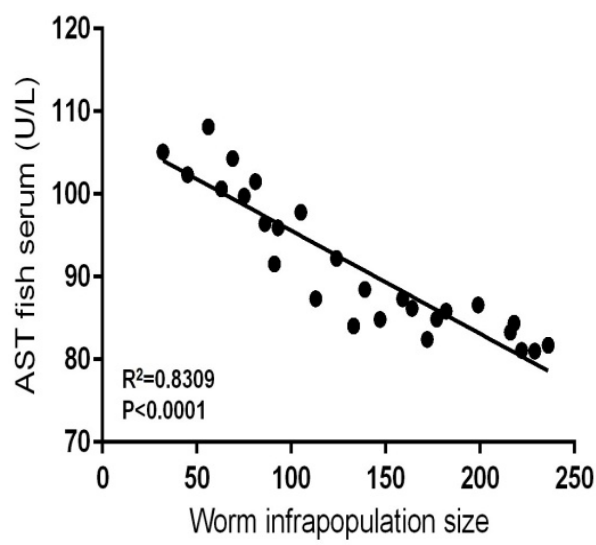

(b)

Figure 3. Cont. 


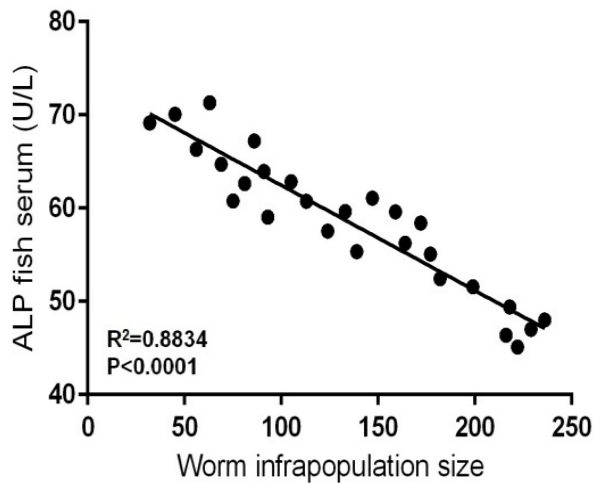

(c)

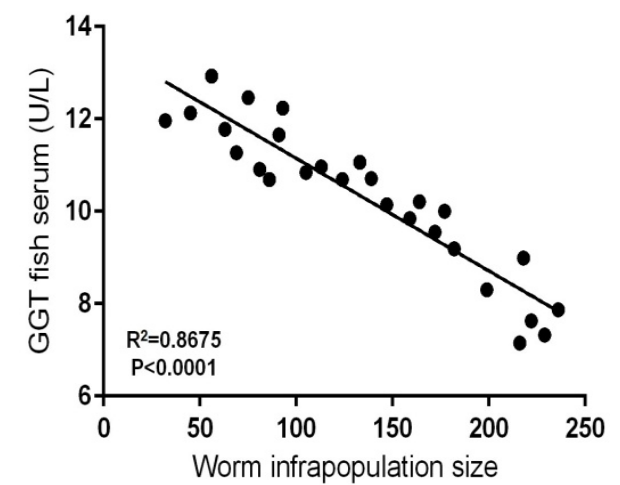

(d)

Figure 3. The relationships between levels of serum liver enzymes and worm infrapopulation size in fish intestine: (a) ALT level in fish serum vs. worm infrapopulation size, (b) AST level in fish serum vs. worm infrapopulation size, (c) ALP level in fish serum vs. worm infrapopulation size, (d) GGT level in fish serum vs. worm infrapopulation size.

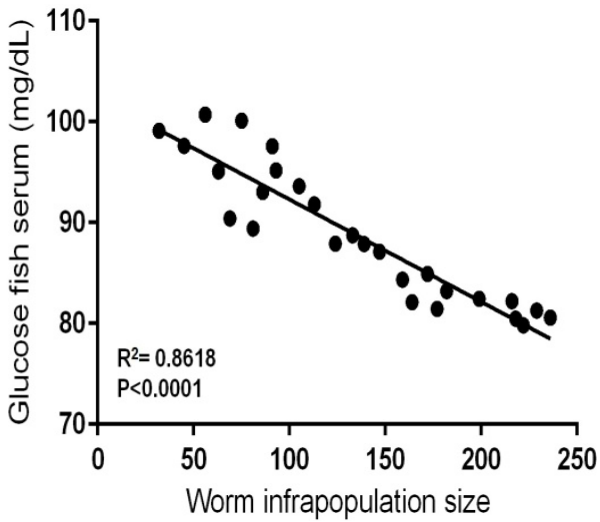

(a)

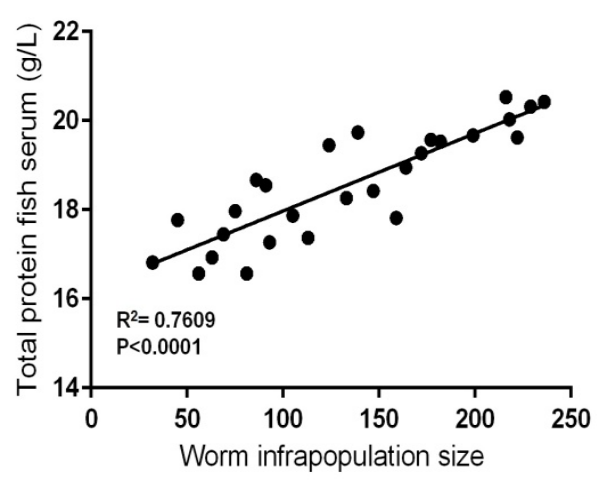

(c)

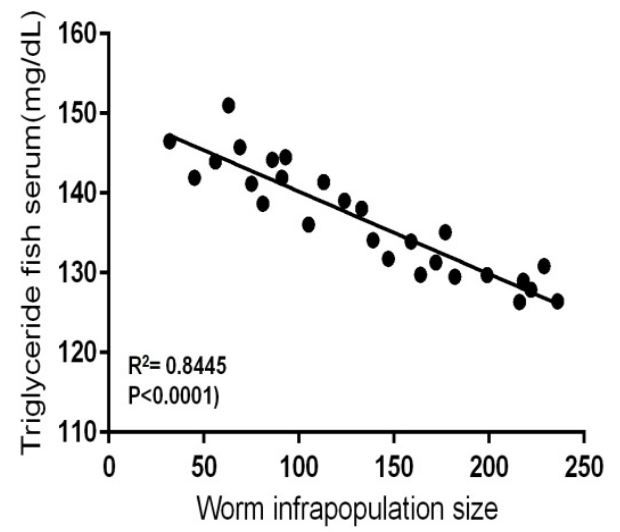

(b)

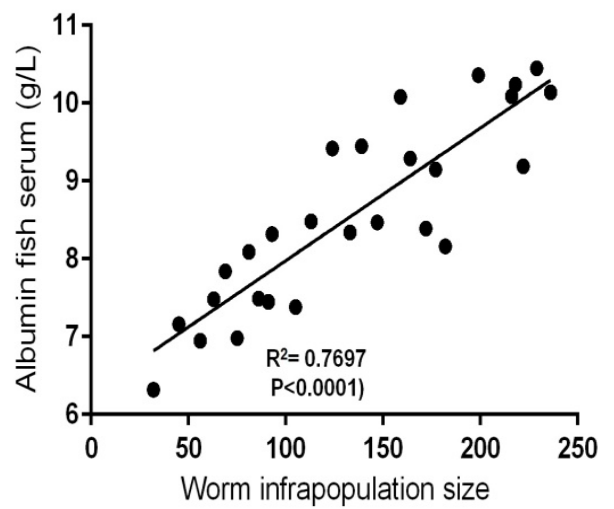

(d)

Figure 4. Cont. 


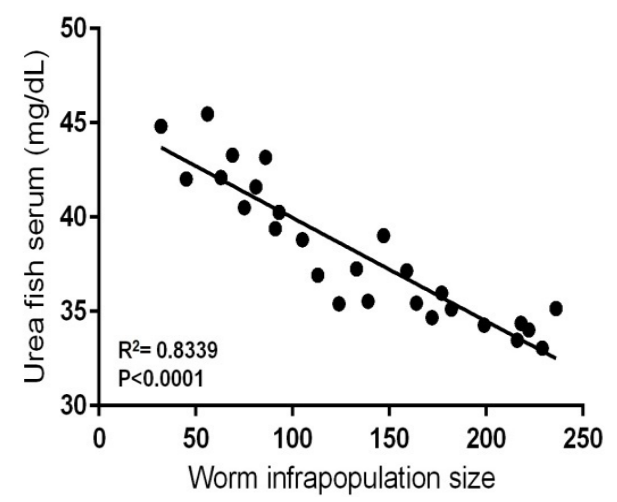

(e)

Figure 4. The relationships between levels of selected biochemical parameters in fish blood serum and worm infrapopulation size in fish intestine: (a) glucose level in fish serum vs. worm infrapopulation size, (b) triglycerides level in fish serum vs. worm infrapopulation size, (c) total protein level in fish serum vs. worm infrapopulation size, (d) albumin level in fish serum vs. worm infrapopulation size, (e) urea level in fish serum vs. worm infrapopulation size.

\section{Discussion}

In the current study, the accuracy of the analytical procedures carried out by the Coupled Plasma-Mass Spectrometer (ICP-MS) was about 96\%, which can be considered a reliable analysis.

In aquatic environments contaminated with toxic metals (e.g., $\mathrm{Cd}, \mathrm{Pb}, \mathrm{Hg}$, $\mathrm{As}$ ), the accumulation of these metals the different organs of fish adversely affects its health by causing severe tissue damage, various biochemical and functional disorders, and serious chronic diseases in these organs (3-6). Similarly, acanthocephalan worms, due to their armed proboscises, adversely affect the health of their fish hosts by damaging the nature of intestinal tissue in these hosts at the attachment sites, causing severe histological and histopathological changes [15-22]. In contrast, several studies [13,23,24,31] have pointed to a beneficial impact of acanthocephalans on their fish hosts because these worms have much higher potential and capacity than their fish hosts to bioaccumulate different metals, especially the toxic ones, and thus can minimize the amounts of heavy metals in the tissues of these fish hosts. However, numerous studies [13,26-29,32,34] revealed that metal concentrations in the tissues of acanthocephalan-infected fish were significantly less than those of uninfected conspecifics. In aquatic environments, heavy metals are generally bound to suspended particles or adsorbed on particulate organic matter, and only minute portions of them are present in water as free ions (hydrated) and identified as "biologically available metals", i.e., can be taken up directly from water by living organisms. These portions are affected by several environmental factors, such as water salinity, temperature, $\mathrm{pH}$, etc. [60]. Fishes absorb heavy metals through their gills or intestinal wall, and in the liver, most metals are removed from blood to incorporate in organometallic complexes carried by bile into the small intestine, where these complexes can be re-absorbed through the intestinal wall into the general circulation or eliminated in fish feces [23,61,62]. Acanthocephalans interfere with this re-absorption and absorb organometallic or bile complexes via their tegument with greater efficiency than the intestinal wall of the fish host $[23,63]$. Thus, the amounts of bile complexes that are usually re-absorbed by the fish intestinal wall are significantly reduced. Our results showed that metal $(\mathrm{Cd} \mathrm{or} \mathrm{Pb})$ concentrations in the liver of fish infected with S. rubrimaris were distinctly lower than those in uninfected conspecifics. This decline in metal concentrations due to their uptake by acanthocephalans has been recorded in numerous studies $[13,23,24,28,32,33,35,64-66]$. However, our results revealed that $\mathrm{S}$. rubrimaris bioconcentrates $\mathrm{Cd}$ and $\mathrm{Pb}$ at levels about 91- and 13-fold higher than in fish liver, i.e., this worm has a high ability or capacity to easily absorb and bioaccumulate considerable amounts of these metals from fish intestine. Thus, the present host-parasite 
system, Siganus rivulatus-Sclerocollum rubrimaris seems to be very useful for biomonitoring trace metal pollution in the Red Sea. Additionally, our results revealed clear negative relationships between $\mathrm{Cd}$ or $\mathrm{Pb}$ concentrations in the liver of infected fish and S. rubrimaris infrapopulation size, i.e., as the worm infrapopulation size increases in fish intestine, the concentrations of both $\mathrm{Cd}$ and $\mathrm{Pb}$ in fish liver significantly decrease. Moreover, there were clear negative relationships between $\mathrm{Cd}$ and $\mathrm{Pb}$ concentrations in S. rubrimaris and its infrapopulation size, i.e., as the worm infrapopulation size in fish intestine increased, the concentration of both $\mathrm{Cd}$ and $\mathrm{Pb}$ in its individuals significantly decreased. This decrease firmly suggests intraspecific competition among $S$. rubrimaris individuals for absorption the available amounts of these metals from fish intestine. This pattern of competition for host intestinal resources is well known in acanthocephalan infrapopulations $[13,28,63,67,68]$.

In ecotoxicology, serum liver enzymes such asALT, AST, ALP, and GGT are commonly used as sensitive biomarkers to elucidate the impact of water pollutants on fish health [69-71]. ALT and AST are essential amino acid-metabolizing enzymes in the liver of teleost fishes $[36,37,72,73]$, ALP is contained in a membrane-bound vacuoles in hepatocytes and osteocytes and plays a vital role [36], and GGT is an abundant enzyme in hepatocytes and plays an essential role in xenobiotic detoxification [36]. Serum levels of these enzymes are mostly increased in fishes exposed to heavy metal pollution [45,74-78]. This increase may be due to the toxic impact of these metals on fishes and points to histological damage in some organs, particularly the liver $[76,78,79]$. Serum liver enzymes are originally intracellular and are released into bloodstream following cellular damage [45,80-82] since toxicants such as heavy metals increase the permeability of damaged hepatocytes, and consequently enzymes leak out of the liver into the bloodstream and their levels increase. Such an increase leads to anorexia and fatigue $[39,40]$. In the current study, mean Cd and $\mathrm{Pb}$ concentrations in the liver of contaminated-uninfected fishes were distinctly high and led to a significant increase in the levels of serum liver enzymes (ALT, AST, ALP, and GGT), exceeding those in the reference group. Such an increase in the levels of these enzymes in fishes, due to heavy metal pollution, has been reported in numerous studies $[45,78,83]$. Several studies on the impact of helminth parasites on blood biochemical parameters of their host fishes [46-50] have shown that infection of fishes with helminth parasites such as monogeneans, cestodes and nematodes significantly increases the levels of serum liver enzymes. Controversially, our results revealed that mean $\mathrm{Cd}$ and $\mathrm{Pb}$ concentrations in the liver of contaminated-infected fishes significantly reduced to approximately half that in uninfected fishes, and, consequently, serum liver enzymes in infected fishes significantly decreased towards their levels in the reference group. These results firmly suggest that infection with acanthocephalans mitigates the impacts of elevated serum liver enzymes on their fish hosts by absorbing considerable amounts of heavy metals from fish intestine.

In fishes, serum glucose level is a sensitive indicator for environmental stress [84-86], and significantly increases (hyperglycemia) after exposure to heavy metal pollution [71,87-89]. Hyperglycemia leads to reduced growth, high feed conversion ratio, and low sustainable growth rate. Toxicity of these metals leads to severe liver damage and stress conditions, which together adversely affect carbohydrate metabolism in fish liver and consequently blood glucose level significantly increases $[51,83,90]$. In agreement with these observations, our results revealed that mean serum glucose level in contaminated-uninfected fishes was significantly higher than its level in the reference group. Few studies $[48,91]$ have shown that infection with helminth parasites, such as monogeneans, cestodes, and nematodes, significantly increases serum glucose level in infected fishes. On the contrary, our results revealed that mean serum glucose level in contaminated-infected fishes significantly decreased towards its level in reference group and was significantly lower than that in contaminated-uninfected fishes. This firmly suggests that infection with acanthocephala mitigates the impact of elevated blood glucose level on their fish hosts by absorbing considerable amounts of heavy metals from the fish's intestine.

Serum triglyceride level is an essential indicator for the metabolic status of fish and is usually increased (hypertriglyceridemia) in fishes living in polluted environments; 
hypertriglyceridemia can cause fatty deposits in the internal organs and blockage of blood vessels $[92,93]$. Significantchanges in its levelpoint to liver dysfunction and consequently inhibition of lipid catabolism [92-95]. Similarly, our results revealed that the mean serum triglyceride level in contaminated-uninfected fishes was significantly higher than its level in the reference group. Generally, studies on the impact of helminth parasites on serum triglycerides level in their host fishes are unavailable. Our results revealed that the mean serum triglyceride level in contaminated-infected fishes significantly decreased towards its level in the reference group and was significantly lower than that in contaminateduninfected fishes. This strongly suggests that infection with acanthocephala mitigates the impact of elevated serum triglycerides level on their fish hosts by absorbing considerable amounts of heavy metals from fish intestine.

In fishes, the serum total protein (STP) level is an essential indicator for liver integrity and general health status [40,41]. STP usually decreases (hypoproteinemia) in fishes inhabiting polluted environments; hypoproteinemia mostly causes slowed growth, muscle loss, and a weakened immune system. The decrease in STP level is mostly due to severe liver damage and stress conditions $[44,96]$. In agreement with these observations, our results showed that the mean STP level in contaminated-uninfected fishes was significantly lower than its level in the reference group. Several studies $[48,91]$ have shown that infection with helminth parasites, such as monogeneans, cestodes, and nematodes, significantly decreases the STP level in infected fishes.On the contrary, our results revealed that the mean STP level in contaminated-infected fishes moderately increased towards its level in the reference group and was moderately higher than that in contaminated-uninfected fishes. This strongly suggests that infection with acanthocephala mitigates the impact of reduced STP level on their fish hosts by absorbing considerable amounts of heavy metals from fish intestine.This suggestion is supported by the negative relationship between metal concentrations $(\mathrm{Cd}$ or $\mathrm{Pb})$ in fish liver and worm infrapopulation size in fish intestine, and the positive relationship between STP level and worm infrapopulation size in fish intestine.

Serum albumin level in fishes is of considerable diagnostic value and refers to the integrity of vascular system and liver functions [43], and it usually decreases (hypoalbuminemia) in fishes with severe liver damage due to chronic exposure to pollutants [43,97]. Hypoalbuminemia adversely affect the transport functions through the vascular system fish [43]. Generally, the degree of deficiency in serum albumin level is directly proportional to the degree of liver damage [98]. These findings are consistent with our results, which revealed that mean serum albumin level in contaminated-uninfected fishes was significantly lower than its level in the reference group. No previous studies are available on the impact of helminth parasites on serum albumin level in their host fishes. Amazingly, our results revealed that mean serum albumin level in contaminated-infected fishes moderately increased towards its level in the reference group and was significantly higher than that in contaminated-uninfected fishes. This strongly suggests that infection with acanthocephala mitigates the impact of reduced serum albumin level on their fish hosts by absorbing considerable amounts of heavy metals from fish intestine.

Serum urea level is an essential indicator for the metabolic status of fish and is usually increased (hyperuricemia) in fishes living in polluted environments due to gill and liver diseases $[42,99,100]$ since urea in fish is formed by the liver and execrated mainly by gills as ammonia, and a small amount is excreted by the kidneys as urine [101]. The excess amount of urea (at a high concentration) poisons the cells and adversely affects various cellular processes $[42,101]$. Our results fully agree with these findings since the mean serum urea level in contaminated-uninfected fishes was significantly higher than its level in the reference group. Many studies $[47,49,50]$ have revealed that helminth parasites, such as monogeneans, cestodes, and nematodes, significantly increase serum urea level in their fish hosts. Controversially, our results revealed that the mean serum urea level in contaminatedinfected fishes significantly decreased towards its level in the reference group and was significantly lower than that in contaminated-uninfected fishes. This robustly suggests 
that infection with acanthocephala mitigates the impact of elevated serum urea level on their fish hosts by absorbing considerable amounts of heavy metals from fish intestine.

In addition to the above, our results are reinforced by the negative relationships between metal concentration $(\mathrm{Cd}$ or $\mathrm{Pb})$ in fish liver, levels of serum liver enzymes, level of serum glucose, level of serum triglycerides, or level of serum urea and worm infrapopulation size in fish intestine, and by the positive relationship between STP level or serum albumin level and worm infrapopulation size in fish intestine.

\section{Conclusions}

Our results entirely agree with most previous studies in that gutless helminth parasites that absorb their nutrients through their tegument from fish intestine, such as acanthocephalan worms, are a good entryfor trace metal pollution, and the current host-parasite system, Siganus rivulatus-Sclerocollum rubrimaris seems to be very useful for biomonitoring trace metal pollution in the Red Sea. However, the combination of our results suggests that infection with acanthocephalans mitigates the harmful impacts of trace metal pollution on their fish hosts because infection with these worms: (1) significantly decreases the elevated concentrations of both $\mathrm{Cd}$ and $\mathrm{Pb}$ in fish liver by absorbing and bioaccumulating considerable amounts of these metals from fish intestine; (2) significantly decreases the elevated levels of liver enzymes, glucose, triglycerides, and urea in fish blood serum towards their levels in the reference group; and (3) moderately increases the declined levels of total protein and albumin in fish blood serum towards their levels in the reference group. Finally, we can say that "acanthocephalan worms are not absolutely harmful to their fish hosts, but sometimes have beneficial impacts on these hosts".

Author Contributions: Both authors (R.H. and Z.A.-H.) shared equally in writing this research article. All authors have read and agreed to the published version of the manuscript.

Funding: This research received no external funding.

Institutional Review Board Statement: The study was conducted according to the guidelines of the Declaration of Helsinki, and approved by the current Egyptian regulations of Institutional Animal Care and Use Committee (local IACUC-Cairo University, Cairo, Egypt: approval code, CU/F/8365: $7 / 1 / 2020)$, the Egyptian universities guidelines for the care of experimental animals, and with the Egyptian Environmental Affairs Agency (EEAA).

Data Availability Statement: Data are contained within the article.

Acknowledgments: We are very grateful to Rabigh-Faculty of Science and Arts, King Abdulaziz University, Saudi Arabia, for continued encouragement and support. We should like to extend our appreciation to the staff of the Red Sea Diving Center, Sharm El-Sheikh, South Sinai, Egypt, for their help during the collection of the material.

Conflicts of Interest: The authors declare that they have no conflict of interest.

\section{References}

1. Jezierska, B.; Witeska, M. The metal uptake and accumulation in fish living in polluted waters. In Soil and Water Pollution Monitoring, Protection and Remediation, 1st ed.; Twardowska, I., Allen, H.E., Häggblom, M.M., Stefaniak, S., Eds.; NATO Science Series; Springer: Dordrecht, The Netherland, 2006; Volume 69, pp. 7-14.

2. Fazio, F.; Piccione, G.; Tribulato, K.; Ferrantelli, V.; Giangrosso, G.; Arfuso, F.; Faggio, C. Bioaccumulation of heavy metals in blood and tissue of striped mullet in two Italian lakes. J. Aquat. Anim. Health 2014, 26, 278-284. [CrossRef] [PubMed]

3. Al-Busaidi, M.; Yesudhason, P.; Al-Mughairi, S.; Al-Rahbi, W.A.K.; Al-Harthy, K.S.; Al-Mazrooei, N.A.; Al-Habsi, S.H. Toxic metals in commercial marine fish in Oman with reference to national and international standards. Chemosphere 2011, 85, 67-73. [CrossRef]

4. Rahman, M.S.; Molla, A.H.; Saha, N.; Rahman, A. Study on heavy metals levels and its risk assessment in some edible fishes from Bangshi River Savar, Dhaka, Bangladesh. Food. Chem. 2012, 134, 1847-1854. [CrossRef] [PubMed]

5. Moustafa, M.Z.; El-Sayed, E.M. Impact of water pollution with heavy metals on fish health: Overview and updates. Glob. Vet. 2014, 12, 219-231.

6. Javed, M.; Usmani, N. An overview of the adverse effects of heavy metal contamination on fish health. Proc. Natl. Acad. Sci. USA India Sect. B Biol. Sci. 2019, 89, 389-403. [CrossRef]

7. Kojima, Y.; Kagi, J.H.R. Metallothionein. Trends Biochem. Sci. 1978, 3, 90-93. [CrossRef] 
8. Buckley, J.T.; Roch, M.; McCarter, J.A.; Rendell, C.A.; Matheson, A.T. Chronic exposure of Coho salmon to sublethal concentration of copper. Effect on growth, on accumulation out distribution of copper and on copper tolerance. Comp. Biochem. Physiol. 1992, 72C, 15-19.

9. Heath, A.G. Water Pollution and Fish Physiology, 2nd ed.; CRC Press (Taylor \& Francis Group): London, UK, 1995; pp. 1-384.

10. Dural, M.; LugalGöksu, M.Z.; Özak, A.A.; Derici, B. Bioaccumulation of some heavy metals in different tissues of Dicentrarchus labrax L, 1758, Sparus aurata L, 1758 and Mugil cephalus L, 1758 from the ÇamlIk lagoon of the eastern cost of Mediterranean (Turkey). Environ. Monit. Assess. 2006, 118, 65-74. [CrossRef]

11. Yousafzai, A.M.; Khan, A.R.; Shakoori, A.R. Trace metal accumulation in the liver of an endangered South Asian fresh water fish dwelling in sublethal pollution. Pak. J. Zool. 2009, 41, 35.

12. Kelle, H.I.; Ngbede, E.O.; Oguezi, V.U.; Ibekwe, F.C. Determination of heavy metals in fish (Clarias gariepinus) organs from Asaba Major Markets, Delta State, Nigeria. Am. Chem. Sci. J. 2015, 5, 135-147.

13. Hassanine, R.M.; Al-Hasawi, Z.M.; Hariri, M.S.; Touliabah, H.E.-S. Sclerocollum saudii Al-Jahdali, 2010 (Acanthocephala: Cavisomidae) as a sentinel for heavy-metal pollution in the Red Sea. J. Helminthol. 2019, 93, 177-186. [CrossRef]

14. Ribas, A.; Casanova, J.C. Acanthocephalans. In Micro Mammals and Macroparasites: From Evolutionary Ecology to Management, 1st ed.; Morand, S., Krasnov, B., Poulin, R., Eds.; Springer: Berlin, Germany, 2006; pp. 81-89.

15. Taraschewski, H. Host-parasite interactions in Acanthocephala: A morphological approach. Adv. Parasitol. 2000, 46, 1-179.

16. Dezfuli, B.S.; Giari, L.; Simoni, E.; Bosi, G.; Manera, M.A. Histopathology, immunohistochemistry and ultrastructure of the intestine of Leuciscus cephalus (L.) naturally infected with Pomphorhynchus laevis (Acanthocephala). J. Fish Dis. 2002, 25, 7-14. [CrossRef]

17. Dezfuli, B.S.; Pironi, F.; Giari, L.; Domeneghini, C.; Bosi, G. Effect of Pomphorhynchus laevis (Acanthocephala) on putative neuromodulators in the intestine of naturally infected Salmo trutta. Dis. Aquat. Org. 2002, 51, 27-35. [CrossRef] [PubMed]

18. Kim, S.; Lee, J.S.; Kim, J.; Oh, M.; Kim, C.; Park, M.A.; Park, J.J. Fine structure of Longicollum pagrosomi (Acanthocephala: Pomphorhynchidae) and intestinal histopathology of the red sea bream, Pagrus major, infected with acanthocephalans. Parasitol. Res. 2011, 109, 175-184. [CrossRef] [PubMed]

19. Salah Eldeen, Y.M.H.; Omer, F.I.; Murwan, K.S.; Mohamed, I.A. Histopathological alterations in small intestine of rabbit fish (Siganus rivulatus) infected by helminth parasite (Sclerocollum sp.), Red Sea coast, Sudan. Int. J. Environ. 2014, 3, 216-228. [CrossRef]

20. De Matos, L.V.; de Oliveira, M.I.B.; Gomes, A.L.S.; da Silva, G.S. Morphological and histochemical changes associated with massive infection by Neoechinorhynchus buttnerae (Acanthocephala: Neoechinorhynchidae) in the farmed freshwater fish Colossomam acropomum Cuvier, 1818 from the Amazon State, Brazil. Parasitol. Res. 2017, 116, 1029-1037. [CrossRef] [PubMed]

21. Amin, O.M.; Heckmann, R.A.; Bannai, M.A. Cavisoma magnum (Cavisomidae), a unique Pacific acanthocephalan redescribed from an unusual host, Mugil cephalus (Mugilidae), in the Arabian Gulf, with notes on histopathology and metal analysis. Parasite 2018, 25, 5. [CrossRef] [PubMed]

22. Aguiar, L.S.; de Oliveira, M.I.B.; de Matos, L.V.; Gomes, A.L.S.; da Costa, J.I.; da Silva, G.S. Distribution of the acanthocephalan Neoechinorhynchus buttnerae and semiquantitative analysis of histopathological damage in the intestine of tambaqui (Colossoma macropomum). Parasitol. Res. 2018, 117, 1689-1698. [CrossRef] [PubMed]

23. Sures, B.; Siddall, R. Pomphorhynchus laevis: The intestinal acanthocephalan as a lead sink for its fish host, chub (Leuciscus cephalus). Exp. Parasitol. 1999, 93, 66-72. [CrossRef] [PubMed]

24. Sures, B. Accumulation of heavy metals by intestinal helminths in fish: An overview and perspective. Parasitology 2003, 126, S53-S60. [CrossRef]

25. Sures, B. Environmental parasitology: Relevancy of parasites in monitoring environmental pollution. Trends Parasitol. 2004, 20, 170-177. [CrossRef] [PubMed]

26. De Buron, I.; James, E.; Riggs-Gelasco, P.; Ringwood, A.H.; Rolando, E.; Richardson, D. Overviewof the status of heavy metal accumulation by helminthes with a note on the use of in vitro culture of adult acanthocephalans to study the mechanisms of bioaccumulation. J. Appl. Ichthyol. 2009, 3, 101-110.

27. Nachev, M.; Schertzinger, G.; Sures, B. Comparison of the metal accumulation capacity between the acanthocephalan Pomphorhynchus laevis and larval nematodes of the genus Eustrongylides sp. infecting barbel (Barbus barbus). Parasites Vectors 2013, 6, 21. [CrossRef]

28. Al-Hasawi, Z.M. Environmental Parasitology: Intestinal helminth parasites of the siganid fish Siganus rivulatus as bioindicators for trace metal pollution in the Red Sea. Parasite 2019, 26, 1-12. [CrossRef] [PubMed]

29. Duarte, G.S.C.; Lehun, A.L.; Lucas, R.L.A.; Consolin-Filho, N.; Bellay, S.; Takemoto, R.M. Acanthocephalans parasites of two Characiformes fishes as bioindicators of cadmium contamination in two neotropical rivers in Brazil. Sci. Total Environ. 2020, 738, 1-8. [CrossRef]

30. Sures, B.; Dezfuli, B.S.; Krug, H.F. The intestinal parasite Pomphorhynchus laevis (Acanthocephala) interferes with the uptake and accumulation of lead $(210 \mathrm{~Pb})$ in its fish host chub (Leuciscus cephalus). Int. J. Parasitol. 2003, 33, 1617-1622. [CrossRef]

31. Mehana, E.E.; Khafaga, A.F.; Elblehi, S.S.; Abd El-Hack, M.E.; Naiel, M.A.E.; Bin-Jumah, M.; Othman, S.I.; Allam, A.A. Biomonitoring of heavy metal pollution using acanthocephalans parasite in ecosystem: An updated overview. Animals 2020, 10, 811. [CrossRef] 
32. Brázová, T.; Hanzelová, V.; Miklisová, D.; Šalamún, P.; Vidal-Martínez, V.M. Host-parasite relationships as determinants of heavy metal concentrations in perch (Perca fluviatilis) and its intestinal parasite infection. Ecotoxicol. Environ. Saf. 2015, 122, 551-556. [CrossRef]

33. Nachev, M.; Sures, B. Environmental parasitology: Parasites as accumulation bioindicators in the marine environment. J. Sea Res. 2016, 113, 45-50. [CrossRef]

34. Paller, V.G.V.; Resurreccion, D.J.B.; de la Cruz, C.P.P.; Bandal, M.Z. Acanthocephalan parasites (Acanthogyrus sp.) of Nile tilapia (Oreochromis niloticus) as biosink of lead $(\mathrm{Pb})$ contamination in a Philippine freshwater lake. Bull. Environ. Contam. Toxicol. 2016, 96, 810-815. [CrossRef]

35. Sures, B.; Nachev, M.; Selbach, C.; David, J.; Marcogliese, D.J. Parasite responses to pollution: What we know and where we go in 'Environmental Parasitology'. ParasitesVectors 2017, 10, 65. [CrossRef] [PubMed]

36. Murray, R.K.; Granner, D.K.; Mayes, P.A.; Rodwell, V.W. Harper's Illustrated Biochemistry, 26th ed.; McGraw-Hill Companies, Inc.: New York, NY, USA, 2003; pp. 1-693.

37. Coz-Rakovac, R.; Smuc, T.; Topic Popovic, N.; Strunjak-Perovic, I.; Hacmanjek, M.; Jadan, M. Novel methods for assessing fish blood biochemical data. J. Appl. Ichthyol. 2008, 24,77-80. [CrossRef]

38. Nordlie, R.C.; Foster, J.D.; Lange, A.J. Regulation of glucose production by the liver. Ann. Rev. Nutr. 1999, 19, 379-406. [CrossRef] [PubMed]

39. Sandre, L.C.G.; Buzollo, H.; Neira, L.M.; Nascimento, T.M.T.; Jomori, R.K.; Carneiro, D.J. Growth and energy metabolism of Tambaqui (Colossoma macropomum) fed diets with different levels of carbohydrates and lipids. Fish. Aquacul. J. $2017,8,3$.

40. Schaperclaus, W.; Kulow, H.; Schreckenbach, K. Fish Disease, 5th ed.; A.A. Balkema Press: Rotterdam, The Netherlands, 1992; pp. 1-1398.

41. Yang, J.L.; Chen, H.C. Serum metabolic enzyme activities and hepatocyte ultrastructure of common carp after gallium exposure. Zool. Stud. 2003, 42, 455-461.

42. Murray, R.K.D.K.; Rranne, P.A.M.; Rodwell, V.W. Harper's Biochemistry Publisher, 22nd ed.; McGraw-Hill Medical: Norwalk, CT, USA; Los Altos, CA, USA, 1990; pp. 1-720.

43. Gopal, V.; Parvathy, S.; Balasubramanian, R.S. Effect of heavy metals on the blood protein biochemistry of the fish Cyprinus carpio and its use as a bio-indicator of pollution stress. Environ. Monitor. Assess. 1997, 48, 117-124. [CrossRef]

44. Shaheen, T.; Akhtar, T. Assessment of chromium toxicity in Cyprinus carpio through hematological and biochemical blood markers. Turk. J. Zool. 2012, 36, 682-690.

45. Abalaka, S.E. Evaluation of the haematology and biochemistry of Clarias gariepinus as biomakers of environmental pollution in Tiga dam Nigeria. Braz. Arch. Biol. Technol. 2013, 56, 371-376. [CrossRef]

46. El-Seify, M.A.; Zaki, M.S.; Desouky, A.R.Y.; Abbas, H.H.; Abdel Hady, O.K.; Abou Zaid, A.A. Study on clinopathological and biochemical changes in some freshwater fishes infected with external parasites and subjected to heavy metals pollution in Egypt. Life Sci. 2011, 8, 401-405.

47. Ogechi, U.N.; Ejikeme, O.G.; Didiugwu, N.C.; Ncha, O.S.; Onahs, S.P.; Amarachi, A.C. Effect of parasites on the biochemical and haematological indices of some clariid (Siluriformes) catfishes from Anambra River, Nigeria. Int. J. Fish. Aquat. Stud. 2015, 3, 331-336.

48. Abd El-Hamed, H.A.; El-Shaer, W.A. Study on clinicopathological and biochemical changes in some marine water fishes infested with internal parasites in Red Sea. Egypt. J. Chem. Environ. Health 2015, 1, 1017-1031.

49. Rastiannasab, A.; Afsharmanesh, S.; Rahimi, R.; Sharifian, I. Alternations in the liver enzymatic activity of Common carp, Cyprinus carpio in response to parasites, Dactylogyrus spp. and Gyrodactylus spp. J. Parasit. Dis. 2016, 40, 1146-1149. [CrossRef]

50. Omeji, S.; Alo, J.A.; Garba, A.A. Impact of parasites on the haematological and biochemical parameters of selected bagrid species from lower river Benue Nigeria. Int. J. Vet. Sci. Anim. Husb. 2018, 3, $23-27$.

51. Soengas, J.L.; Agra-Lago, M.J.; Carballo, B.; Andres, M.D.; Veira, J.A.R. Effect of an acute exposure to sublethal concentration of cadmium on liver carbohydrate metabolism of Atlantic salmon (Salmo salar). Bull. Environ. Contam. Toxicol. 1996, 57, 625-631. [CrossRef]

52. Schmidt, G.D.; Paperna, I. Sclerocollum rubrimaris gen. et sp. n. (Rhadinorhynchidae: Gorgorhynchinae), and other Acanthocephala of marine fishes from Israel. J. Parasitol. 1978, 64, 846-850. [CrossRef]

53. Diamant, A. Ecology of the acanthocephalan Sclerocollum rubrimaris Schmidt and Paperna, 1978 (Rhadinorhynchidae: Gorgorhynchinae) from wild populations of rabbitfish (genus Siganus) in the northern Red Sea. J. Fish Biol. 1989, 34, 387-397. [CrossRef]

54. Hassanine, R.M. Acanthocephalans from Red Sea fishes. Family Cavisomidae Meyer, 1932: The seasonal cycle of Diplosentisnudus (Harada, 1938) Pichelin et Cribb, 2001 in a definitive fish host, and a comment on Sclerocollum Schmidt et Paperna, 1978. Acta Parasitol. 2006, 51, 123-130. [CrossRef]

55. Zimmermann, S.; Menzel, C.; Berner, Z.; Eckhardt, J.D.; Stüben, D.; Alt, F.; Messerschmidt, J.; Taraschewski, H.; Sures, B. Trace analysis of platinum in biological samples: A comparison between high resolution inductively coupled plasma mass spectrometry (HR-ICP-MS) following microwave digestion and adsorptive cathodic stripping voltammetry (ACSV) after high pressure ashing. Anal. Chim. Acta 2001, 439 (Suppl. 2), 203-209. [CrossRef]

56. Nachev, M. Bioindication Capacity of Fish Parasites for the Assessment of Water Quality in the Danube River. Ph.D. Thesis, Universität Duisburg-Essen, Sofia, Bulgaria, 2010. 
57. Margolis, L.; Esch, G.W.; Holmes, J.C.; Kuris, A.M.; Shad, G.A. The use of ecological terms in parasitology (report of an ad hoc committee of the American Society of Parasitologists). J. Parasitol. 1982, 68, 131-133. [CrossRef]

58. Bush, A.O.; Lafferty, K.D.; Lotz, J.M.; Shostak, A.W. Parasitology meets ecology on its own terms: Margolis et al. revisited. J. Parasitol. 1997, 83, 575-583. [CrossRef]

59. Duncan, D.B. Multiple range and Multiple F-test. Biometrics 1955, 11, 1-42. [CrossRef]

60. Merian, E.; Anke, M.; Ihnat, M.; Stoeppler, M. Elements and Their Compounds in the Environment. Occurrence, Analysis and Biological Relevance, 2nd ed.; Wiley: Weinheim, Germany, 2004; pp. 1-1733.

61. Grahl, K. Erkennung von Schadstoffeinflussen auf die Gesundheit von Fischenmittels Gallendiagnostik. In Fischkrankheiten, 1st ed.; Huskamp, B., Deegen, E., Eds.; Tagung der Fachgruppe Fischkrankheiten: Schmiedefeld, Germany, 1990 ; pp. $240-243$.

62. Hofer, R.; Lackner, R. Fischtoxikologie-Theorie und Praxis, 2nd ed.; Fischer Verlag: Jena, Germany, 1995; pp. 1-164.

63. Sures, B. Competition for minerals between Acanthocephalus lucii and its definitive host perch (Perca fluviatilis). Int. J. Parasitol. 2002, 32, 1117-1122. [CrossRef]

64. Sures, B.; Siddall, R.; Taraschewski, H. Parasites as accumulation indicators of heavy metal pollution. Parasitol. Today 1999, 15, 16-21. [CrossRef]

65. Eira, C.; Torres, J.; Miquel, J.; Vaqueiro, J.; Soares, A.M.; Vingada, J. Trace element concentrations in Proteocephalus macrocephalus (Cestoda) and Anguillicola crassus (Nematoda) in comparison to their fish host, Anguilla anguilla in Ria de Aveiro, Portugal. Sci. Total Environ. 2009, 407, 991-998. [CrossRef] [PubMed]

66. Torres, J.; Eira, C.; Miquel, J.; Ferrer-Maza, D.; Delgado, E.; Casadevall, M. Effect of intestinal tapeworm Clestobothrium crassiceps on concentrations of toxic elements and selenium in European hake Merluccius merluccius from the Gulf of Lion (northwestern Mediterranean Sea). J. Agric. Food Chem. 2015, 63, 9349-9356. [CrossRef]

67. Poulin, R. Evolutionary Ecology of Parasites, 2nd ed.; Princeton University Press: Princeton, NJ, USA, 2006 ; pp. 1-360.

68. Al-Jahdali, M.O.; Hassanine, R.M. El-S. Infrapopulations of Sclerocollum saudii Al-Jahdali, 2010 (Acanthocephala: Cavisomidae) in the rabbitfish Siganus rivulatus (Teleostei, Siganidae) from the Saudi coast of the Red Sea. J. Helminthol. 2012, 86, 85-94. [CrossRef]

69. Kramer, J.W.; Hoffmann, W.E. Clinical Enzymology. In Clinical Biochemistry of Domestic Animals, 5th ed.; Kaneko, J.J., Harvey, J.W., Bruss, M.L., Eds.; Academic Press: San Diego, CA, USA, 1997; pp. 1-315.

70. De La Torre, F.R.; Salibian, A.; Ferrari, L. Biomarkers assessment in juvenile Cyprinus carpio exposed to waterborne cadmium. Environ. Pollut. J. 2000, 109, 277-282. [CrossRef]

71. Levesque, H.M.; Moon, T.W.; Campbell, P.G.C.; Hontela, A. Seasonal variation in carbohydrate and lipid metabolism of yellow perch (Perca flavescens) chronically exposed to metals in the field. Aquat. Toxicol. 2002, 60, 257-267. [CrossRef]

72. Yasutake, W.T.; Wales, J.H. Microscopic Anatomy of Salmonids: An Atlas; United States Department of the Interior, Fish and Wildlife Service, Resource Publication 50: Washington, DC, USA, 1983.

73. Ballantyne, J.S. Amino acid metabolism. In Fish physiology; Wright, P.A., Anderson, P.M., Eds.; Academic Press: New York, NY, USA, 2001; pp. 77-107.

74. Zikic, R.V.; Stajn, S.; Pavlovic, Z.; Ognjanovic, B.I.; Saicic, Z.S. Activities of superoxide dismutase and catalase in erytrocyte and plasma transaminases of goldfish (Carassius auratus gibelio Bloch.) exposed to cadmium. Physiol. Res. 2001, 50, $105-111$.

75. Gabriel, U.U.; George, A.D.I. Plasma enzymes in Clarias gariepinus exposed to chronic levels of round up. Environ. Ecol. 2005, 23, 271-276.

76. Yousafzai, M.A.; Shakoori, R.A. Hepatic response of a fresh water fish against aquatic pollution. Pak. J. Zool. 2011, 43, 209-221.

77. Gholizadeh, Z.T.B.; Banaee, M.; Yousefi, J.A.; Nematdoost, H.B.; Seyed, H.M.H. Effects of selenium (Sel-Plex) supplement on blood biochemical parameters of juvenile Siberian sturgeon (Acipenser baerii). Iran. J. Fish. Sci. 2018, 17, 300-312.

78. Ugbomeh, A.P.; Bob-manuel, K.N.O.; Green, A.; Taylorharry, O. Biochemical toxicity of Corexit 9500 dispersant on the gills, liver and kidney of juvenile Clarias gariepinus. Fish Aquat. Sci. 2019, 15, 22. [CrossRef]

79. Soleimany, V.; Banaee, M.; Mohiseni, M.; Nematdoost, H.B.; Mousavi, D.L. Evaluation of pre-clinical safety and toxicology of Althaea officinalis extracts as naturopathic medicine for common carp (Cyprinus carpio). Iran. J. Fish. Sci. 2016, 15, 613-629.

80. Sallie, R.; Tredger, R.S.; Williams, F. Drugs and the liver. Biopharm Drug Dispos. 1991, 12, 251-259. [CrossRef] [PubMed]

81. Mayne, D.P. Clinical Chemistry in Diagnosis and Treatment, 6th ed.; CRC Press: London, UK, 2002; pp. 1-480.

82. Palanivelu, V.; Vijayavel, K.; Ezhilarasil, B.S.; Balasubramanian, M.P. Influence of insecticidal derivatives (Cartap Hydrochloride) from the marine polychaete on certain enzyme systems of the freshwater fish Orechromis mossambicus. J. Environ. Biol. 2005, 26, 191-196.

83. Al-Asgah, N.A.; Abdel-Wahab, A.A.-W.; El-Sayed, M.Y.; Hassan, Y.A. Haematological and biochemical parameters and tissue accumulations of cadmium in Oreochromis niloticus exposed to various concentrations of cadmium chloride. Saudi J. Biol. Sci. 2015, 22, 543-550. [CrossRef]

84. Silbergeld, K.E. Blood glucose: A sensitive indicator of environmental stress in fish. Bull. Environ. Contam. Toxicol. 1974, 11, 20-25. [CrossRef]

85. Iwama, G.K. Stress in Fish. Ann. N. Y. Acad. Sci. 1998, 851, 1-310. [CrossRef]

86. Gagnon, A.; Jumarie, C.; Hontela, A. Effects of $\mathrm{Cu}$ on plasma cortisol and cortisol secretion by adrenocortical cells of rainbow trout (Oncorhynchus mykiss). Aquat. Toxicol. 2006, 78, 59-65. [CrossRef] [PubMed]

87. Richard, A.C.; Daniel, C.; Anderson, P.; Hontela, A. Effects of subchronic exposure to cadmium chloride on endocrine and metabolic functions in rainbow trout Oncorhynchus mykiss. Arch. Environ. Contam. Toxicol. 1998, 34, 377-381. [CrossRef] [PubMed] 
88. Begg, K.; Pankhurst, N.W. Endocrine and metabolic responses to stress in a laboratory population of the tropical damselfish Acanthochromis polyacanthus. J. Fish Biol. 2004, 64, 133-145. [CrossRef]

89. Jagadeshwarlu, R.; Sunitha Devi, G. Effect of Sublethal copper exposure on glycogen, glucose and total lipid levels in (muscle and liver) fish, Oreochromis mossambicus (peters). Int. J. Zool. Stud. 2018, 3, 123-127.

90. Almeida, J.A.; Novelli, E.L.B.; Dal-Pa, I.S.; Alves-Junior, R. Environmental cadmium exposure and metabolic responses of the Nile tilapia Oreochromis niloticus. Environ. Pollut. 2001, 114, 169-175. [CrossRef]

91. Rocha, M.J.S.; Jerônimo, G.T.; Costa, O.T.F.D.; Malta, J.C.O.; Martins, M.L.; Maciel, P.O.; Chagas, E.C. Changes in hematological and biochemical parameters of tambaqui (Colossoma macropomum) parasitized by metazoan species. Rev. Bras. Parasitol. Vet. 2018, 27, 488-494. [CrossRef]

92. Kaplan, A.; Ozabo, L.L.; Ophem, K.E. Clinicalchemistry: Interpretation and Techniques, 3rd ed.; LeaandFebiger: Philadelphia, PA, USA, 1988; pp. 1-400.

93. Hadi, A.A.; Shokr, A.E.; Alwan, S.F. Effects of Aluminum on the Biochemical parameters of Freshwater fish, Tilapia zillii. J. Sci. A 2009, 3, 33-41.

94. Srivastava, N.K.; Prakash, S. Effect of Sublethal Concentration of Zinc Sulphate on the Serum Biochemical Parameters of Freshwater Cat Fish, Clarias batrachus (Linn). Ind. J. Biol. 2018, 5, 113-119.

95. Mohamed, A.S.; ElDesoky, M.A.; Nahed, S.G. The Changes in triglyceride and total cholesterol concentrations in the liver and muscle of two fish species from Qarun Lake. Egypt. Oceanogr. Fish. J. 2019, 9, 555770. [CrossRef]

96. Magnadottir, B.; Gisladottir, B.; Audunsdottir, S.S.; Bragason, B.T. Humeral response in early stages of infection of cod (Cadusmorhua) with a typical furunculosis. Icel. Agric. Sci. 2010, 23, 23-35.

97. Chen, C.Y.; Wooster, G.A.; Bowser, P.R. Comparative blood chemistry and histopathology of tilapia infected with Vibrio vulnificus or Streptococcus iniae or exposed to carbon tetrachloride, gentamicin, or copper sulphate. Aquaculture 2004, 239, 421-443. [CrossRef]

98. Ribeiro, A.J.S.; Yang, X.; Patel, V.; Madabushi, R.; Strauss, D.G. Liver Microphysiological Systems for Predicting and Evaluating Drug Effects. Clin. Pharmacol. Ther. 2019, 106, 139-147. [CrossRef] [PubMed]

99. Stoskopf, M.K. Fish Medicine, 1st ed.; WB Saunders Company: Philadelphia, PA, USA; London, UK, 1993 ; pp. 1-902.

100. Alkaladi, A.; NasrEl-Deen, N.A.M.; Afifi, M.; AbuZinadah, O.A. Hematological and biochemical investigations on the effect of vitamin E and C on Oreochromis niloticus exposed to zinc oxide nanoparticles. Saudi. J. Biol. Sci. 2015, 22, 556-563. [CrossRef]

101. Randall, D.J.; Wright, P.A. Ammonia distribution and excretion in fish. Fish Physiol. Biochem. 2005, 3, 107-120. [CrossRef] [PubMed] 